\title{
МЕТОДИ СИСТЕМНОЇ БІОЛОГІЇ В ОЦІЮЮАННІ ГЛОБАЛЬНИХ ПЕРЕБУДОВ КЛІТИННОГО МЕТАБОЛІЗМУ ПРИ ХРОНІЧНИХ ЗАХВОРЮВАННЯХ ОБМІНУ РЕЧОВИН
}

\author{
О. П. Мінцер, В. М. Заліський \\ Національна медична академія післядипломної освіти імені П. Л. Шупика \\ ${ }^{1}$ ДУ «Національний науковий центр «Інститут кардіології \\ імені академіка М. Д. Стражеска» НАМН України»
}

\begin{abstract}
Системна біологія дозволяє застосовувати математичні моделі для аналізу великих наборів даних і допомагає здійснювати моделювання динаміки складних біологічних систем. В аналітичному дослідженні обговорюються питання використання системного підходу для просування процесів розвитку персоналізованої медицини в лікуванні хвороб обміну речовин, інсулінорезистентності, ожиріння, неалкогольної жирової хвороби печінки, неалкогольного стеатогепатиту та злоякісних новоутворень. Розглянуто результати інтегрального аналізу великих наборів даних для ідентифрікації нових біомаркерних молекул, що $є$ основою персоналізованої терапії. Показано, що кількісний системний аналіз може дати нове уявлення про молекулярні механізми в клітині, ссормувати нові концепції організації, координації і регулювання клітинних процесів. Украй необхідна конвергенція експериментального та in silico аналізу як окремих клітинних процесів, так і технологічних мереж. Підкреслюється, що системно-біологічний і системно-медичний аналізи вимагають широкого застосування мультидисциплінарних і трансдисциплінарних підходів, як це було продемонстровано на прикладі секвенування цілих геномів. Запропоновано використовувати багатоступеневу систему математичного моделювання в форматі in silico з оцінюванням вірогідності кожної 3 ключових подій, що забезпечують виконання каскаду біохімічних реакцій.
\end{abstract}

Ключові слова: системна біологія, системна медицина, метаболізм у клітині, мультидисциплінарні та трансдисциплінарні підходи, моделювання in silico.

\section{ROLE OF THE SYSTEM BIOLOGY IN GLOBAL MODIFICATIONS OF CELLULAR METABOLISM IN CHRONIC METABOLIC DISORDERS}

\author{
O. P. Mintser, V. M. Zalisky ${ }^{1}$ \\ National Medical Academy of Postgraduate Education \\ ${ }^{1}$ National Scientific Center «M. D. Strazhesko Institute of Cardiology» NAMS of Ukraine
}

\begin{abstract}
Background. System biology allows the use of mathematical models to analyze large data sets and helps to simulate the dynamics of complex biological systems. The analytical study discusses the use of the system approach to promote the development of personalized medicine in the treatment of metabolic diseases, insulin resistance, obesity, non-alcoholic fatty liver disease, non-alcoholic steatohepatitis and malignant neoplasms.

Results. The purpose of the study: evaluate the effectiveness of using system biology and system medicine, as well as propose new approaches.

The results of the integral analysis of large data sets for the identification of new biomarker molecules, which are the main personalized therapies, are considered. It is shown that quantitative system analysis can give a new understanding of the molecular mechanisms in the cell, form new concepts for the organization, coordination and regulation of cellular processes. It is extremely necessary to converge experimental and in silico analysis, both individual cellular processes and technological networks.

Conclusions. System-biological and system-medical analyzes require the wide application of multidisciplinary and transdisciplinary approaches, as was demonstrated by the example of sequencing of whole genomes. It is proposed to use a multistage mathematical modeling system in in silico format with an estimation of the probability of each of the key events ensuring the performance of a cascade of biochemical reactions.
\end{abstract}

Key words: system biology, systemic medicine, cell metabolism, multidisciplinary and transdisciplinary approaches, in silico modeling.

\footnotetext{
(с) О. П. Мінцер, В. М. Заліський
} 


\title{
МЕТОДЫ СИСТЕМНОЙ БИОЛОГИИ В ОЦЕНКЕ ГЛОБАЛЬНЫХ ПЕРЕСТРОЕК КЛЕТОЧНОГО ОБМЕНА ПРИ ХРОНИЧЕСКИХ ЗАБОЛЕВАНИЯХ ОБМЕНА ВЕЩЕСТВ
}

\author{
О. П. Минцер, В. Н. Залесский \\ Национальная медицинская академия последипломного образования имени П. Л. Шупика

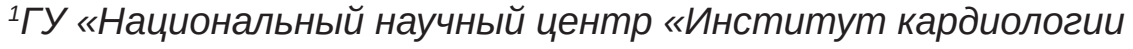 \\ имени академика Н. Д. Стражеско» НАМН Украины»
}

\begin{abstract}
Системная биология позволяет применять математические модели для анализа больших наборов данных и помогает осуществлять моделирование динамики сложных биологических систем. В аналитическом исследовании обсуждаются вопросы использования системного подхода для продвижения процессов развития персонализированной медицины в лечении болезней обмена веществ, инсулинорезистентности, ожирения, неалкогольной жировой болезни печени, неалкогольного стеатогепатита и злокачественных новообразований. Рассмотрены результаты интегрального анализа больших наборов данных для идентисикации новых биомаркерных молекул, являющихся основой персонализированной терапии. Показано, что количественный системный анализ может дать новое представление о молекулярных механизмах в клетке, сформировать новые концепции организации, координации и регулирования клеточных процессов. Крайне необходима конвергенция экспериментального и in silico анализа как отдельных клеточных процессов, так и технологических сетей. Подчеркивается, что системно-биологический и системно-медицинский анализы требуют широкого применения мультидисциплинарных и трансдисциплинарных подходов, как это было продемонстрировано на примере секвенирования целых геномов. Предложено использовать многоступенчатую систему математического моделирования в фрормате in silico c оценкой вероятности каждого из ключевых событий, обеспечивающих выполнение каскада биохимических реакций.
\end{abstract}

Ключевые слова: системная биология, системная медицина, метаболизм в клетке, мультидисциплинарные и трансдисциплинарные подходы, моделирование in silico.

Вступ. Процеси, що протікають у клітині, як власне і ї̈ структури, особливо ядро, є надзвичайно складними. Редукціоністські підходи були вражаюче успішні при вивченні на молекулярному рівні багатьох ключових процесів, що відбуваються в ядрі, особливо експресії генів. Водночас стають очевидними обмеження аналізу одиничних ядерних процесів у просторовій і тимчасовій ізоляції й обгрунтованість узагальнюючих спостережень одиничних генних локусів. Наступний рівень розуміння функцій геному полягає в інтеграції наших знань про їх послідовності та молекулярні механізми, що беруть участь у ядерних процесах, із нашими поглядами на просторову та тимчасову організацію ядра і в з'ясуванні взаємодії між білковими та генними мережами в регуляторних ланцюгах. Для цього необхідні каталоги геномів і протеомів та точне розуміння поведінки молекул у живих клітинах. Зближення технологічних розробок у галузі геноміки, протеоміки, динаміки й обчислень веде до інтегрованого біологічного розуміння біології геному й ядерної функції. Незважаючи на зовні виняткове зростання кількості досліджень, пов'язаних із використанням методології системної біології, ми на даний час знаходимося в початковій стадії розуміння сутності ïï комплексного використання для діагностики та лікування захворювань [7, 15].

Мета дослідження: оцінити ефективність використання методів системної біології і системної медицини, а також запропонувати нові підходи.

Результати та їх обговорення. Активне просування методології системної біології і системної медицини стикається з низкою проблем.

Насамперед, слід зазначити відсутність єдиного формату збору даних, що ускладнює аналіз великих наборів даних.

По-друге, виникають труднощі щодо механістичного трактування цілого ряду біомаркерів і лікарських мішеней; утруднений переклад великих масивів даних (отриманих на основі аналізу геномного моделювання) для клініки i, нарешті, чітко позиціонуються проблеми неоднорідності інформаційних масивів, що вимагають попередньої індивідуальної обробки даних перед проведенням інтегративного аналізу [1, 9, 24]. Ще однією проблемою $\epsilon$ те, що оброблення мультиоміксних даних включає інформаційний ресурс, отриманий у різних динамічних діапазонах їх накопичення.

Серцево-судинні захворювання є основною причиною інвалідності та смертності в економічно розвинених країнах, при цьому на частку ішемічної 
хвороби серця та інфаркту міокарда припадає приблизно дві третини випадків смерті від усіх серцево-судинних захворювань.

Поряд із масивами даних з міжбілкової взаємодії і мРНК, рівні клітинних метаболітів залежать від кінетики окремих ферментів (зокрема від посттрансляційних модифікацій ферментів). До того ж, рівні метаболітів, що циркулюють у крові (метаболіт плазми крові) людини, пов’язані не тільки 3 метаболічною активністю в різних тканинах, але і 3 вживанням харчових інгредієнтів, а також з метаболічною активністю мікробіоти кишечнику [6].

Метаболоміка плазми крові має істотний потенціал для ідентифікації змін стану здоров’я людини. База даних метаболому людини (сайт HMDB Human Metabolic Data Base, www.hmdb.ca) включає приблизно 42000 ідентифікованих метаболітів [16]. Серед них велика кількість харчових метаболітів (близько 2500) і 4500 метаболітів плазми крові [31]. За наявності такого великого масиву продуктів обміну існують труднощі з виявлення біомаркерних молекул, пов’язаних із конкретним захворюванням. Окремі біомаркери при ожирінні та цукровому діабеті було ідентифіковано порівняно нещодавно [2, 32]. Ними виявилися цільові амінокислоти з розгалуженими ланцюгами в складі метаболому плазми крові.

Аналіз транскриптому адипоцитів (після біопсії черевного жиру) у людини показав, що підвищення рівня амінокислот з розгалуженими ланцюгами у пацієнтів із надмірною масою тіла свідчило про зниження дихального обміну в жировій тканині [8]. На думку авторів, наступний глобальний аналіз метаболому у тканинах всього організму може підтвердити важливу роль цих амінокислот як нових прогностичних біомаркерних молекул при ожирінні та цукровому діабеті 2-го типу.

За допомогою повногеномних досліджень у людини було ідентифіковано понад 200 циркулюючих метаболітів у периферичній крові понад 2000 пацієнтів (на тлі проведеного докладного кардіометаболічного фенотипування), а також виявлені вроджені мутації у гені AGXT2, пов’язаному 3 підвищеним рівнем тригліцеридів і холестерину [5]. Перевірено 59 метаболітів у сечі 862 пацієнтів з підвищеним ризиком розвитку захворювань обміну речовин, зокрема виявлено мутацію у гені NAT2, пов'язаному з підвищеним ризиком ішемічної хвороби серця [4].

Добре відомо, що виникнення та розвиток практично будь-якого патологічного процесу призводить до зрушення метаболічного гомеостазу в організмі, що може бути ідентифіковане за допомогою метаболомного аналізу плазми крові. Проте ці зміни слабо реєструються і залишаються малопримітними, якщо відсутній адресний підхід [6].

Останніми роками транскриптомні, протеомні, метаболомні й інші «-омні» масиви даних тканинних реакцій, пов’язаних із хворобою, успішно поєднуються в рамках інтегративного аналізу [25]. Одним із підходів інтегративного аналізу $є$ моделі метаболізму в клітинах у масштабі геному (GEMs, genome-scale metabolic models) [23]. По суті, GEMs-моделі метаболізму в масштабі геному $€$ платформою для аналізу й обгрунтування напрямів дослідження обміну речовин і його участі в підтримці клітинного гомеостазу, бо об’єднують в єдине ціле весь комплекс реакцій обміну, що протікають у кожній клітині, тканинах і організмі. При цьому кожна реакція пов’ язана з одним або більше ферментами і закодована специфічними генами (або групою генів), що дозволяє реєструвати прямі ген-білкові взаємодії.

GEMs дозволяє приєднувати для подальшого аналізу омікс-асоційовані блоки даних (що нагадує збирання скаффолд-біоконструкцій в біоінженерії), наприклад транскриптомних і протеомних масивів, і таким чином сприяти виявленню функціональних властивостей саморегульованих підмереж, що дозволяють визначати спрямованість метаболізму і беруть участь у підтримці клітинного гомеостазу. Часто подібна підмережева структура пов'язана з функціонуванням різних метаболічних шляхів, а також дозволяє через реперні метаболіти, що володіють вираженим транскрипційним профілем мереж клітинного обміну, і набори пов'язаних генів скоординовано реагувати на генетичні та/або екологічні «потрясіння» [25].

Відомо, що клітинна відповідь на рівні генетичних і екологічних «збурень» часто знаходить своє відображення (i/або опосередковується) у змінах метаболізму. Наприклад, якщо клітини зазнають дії оксидативного стресу, то можуть відбуватися зміни не тільки в метаболізмі глутатіону (який безпосередньо бере участь у захисті від окиснювальних реакцій), але й в інших сегментах обміну речовин, зокрема в реакціях пентозофосфатного шляху, що необхідний для забезпечення відновлення НАДФН, що бере участь в обміні глутатіону [15].

Завдяки специфікації стехіометрії різних реакцій у метаболічних мережах GEMs стали використовувати для моделювання метаболічних функцій із 
застосуванням математичного формату такого поняття, як аналіз балансу потоків метаболітів (flux balance analysis) [23]. Дана концепція передбачає, що всі потоки метаболітів у межах індивідуальних тканинних басейнів фактично можна порівняти з такими у межах глобального клітинного пулу організму.

В результаті «збурень» метаболізму швидкі відхилення від стандартного стану потоків метаболітів у різних тканинах організму можуть бути прораховані за допомогою аналізу балансу потоку [20], що дотепер залишається трудомістким завданням через великі ступені свободи розподілу потоків у даних моделях. Водночас, таке глобальне метаболічне перепрограмування сприяє появі відхилень у клітинних функціях і пов’язане з прогресуючим перебігом багатьох захворювань людини.

Порівняно недавно було показано, що включення блоків експериментальних даних з кінетики реакцій каталізу і синтезу ферментів кишкової палички в структуру моделей метаболічних реакцій у масштабі геному дозволило істотно поліпшити передбачувану цінність GEMs [22], а математичне моделювання клітинного метаболізму виявило переважне підвищення обміну лактату в пухлинних клітинах [12].

GEMs-моделі набули поширення у біомедичних програмах, включаючи прогнозування біомаркерів у мережах метаболізму [3]. В зв’язку зі створенням тканеспецифічних GEMs отримані більш детальні дані про мережеві реакції обміну ліпідів [17].

Інтерес становить проблема ідентифікації біомаркерів клітинного обміну. В 2007 році описані перші приклади застосування метаболічного моделювання клітинного метаболізму в масштабі геному людини $[14,30]$. Ці моделі стали основою для розробки клінічних модифікацій версії («Recon 1»), що представляє собою базу знань для моделювання обмінних реакцій у клітині.

За допомогою оцінювання наявності / відсутності білків, що кодуються 14077 генами в адипоцитах, отриманими з різних зразків тканин, в умовах інтеграції масиву з адипоцитоспецифічними даними протеому [19] була ідентифікована група протеїнів, пов’язаних із 7340 генами в адипоцитах людини. Ця інформація дозволила здійснити комплексне моделювання метаболізму в адипоцитах. При цьому модель GEMs адипоцитів (iAdipocytes 1890) послужила біологічним каркасом для інтеграції оміксних даних людини з метою уточнення структури генотип-фенотипічних відносин.
Завдяки інтеграції даних транскриптому людини в моделі GEMs адипоцитів відзначено зменшення дихальної (мітохондріальної) метаболічної активності в жировій тканині у людей з надмірною масою тіла в порівнянні зі здоровими [28]. На тлі збільшення продуктів обміну (андростерону, гангліозиду GM2 і продуктів деградації гепарину сульфату, кератину сульфату), автори розглядають даний підхід як потенційну основу у виявленні мішеней для терапії ожиріння. Водночас, катаболізм амінокислот з розгалуженим ланцюгом (валін, лейцин, ізолейцин) виявився зниженим [8].

Модель GEMs адипоцитів була використана також для ілюстрації динаміки накопичення тригліцеридів і зниження рівня ліпідного обміну у пацієнтів з надмірною масою тіла на тлі ослаблення дихального (мітохондріального) метаболізму [19]. 3 іншого боку, модель GEMs міоцитів дозволила позиціонувати саморегульовані підмережі метаболізму при цукровому діабеті 2-го типу.

Секвенування PHK [29] сприяло оптимізації оцінки біологічних відмінностей між багатьма тканинами у людини при використанні 32 тканеспецифічних GEMs-моделей. Даний підхід дозволив комплексно дослідити клітинний секретом, мембранний протеом, пухлинний протеом і метаболічні функції у багатьох тканинах. Об’єднання всіх масивів в інтерактивну базу даних сприяло проведенню навігації глобальних патернів генної експресії в усіх тканинах організму людини.

Математичне моделювання метаболічних реакцій у масштабі геному ефективно використовувалося з метою створення та дослідження лікарських засобів (Л3) [10, 21, 27]. Персоналізоване GEMs-моделювання було здійснено 6 пацієнтам із гепатоцелюлярною карциномою на основі комплексного аналізу імуногістохімічних і протеомних досліджень, а також обліку даних з бази метаболомних реакцій (GMR2) людини та застосування алгоритму реконструкції (ti NIT) з метою відбору цільових антибластомних препаратів (у рамках концепції антиметаболітів - структурних аналогів метаболітів) [17]. 3104 прогнозованих антиметаболітів 46 виявилися високо ефективними щодо запобігання росту гепатоцелюлярної карциноми. 3 огляду на значну клітинну неоднорідність пухлин печінки отриманий позитивний результат на малій когорті пацієнтів, на думку авторів, недоцільно переносити на великі когорти пацієнтів, що вказує на необхідність здійснення в подальшому 
розроблення більш персоналізованого підходу до терапії новоутворень.

Моделі метаболізму в масштабі геному також виявилися ефективними в узгодженні процесів експресії мережевих генів, незалежно пов'язаних у мережах із різними мутантними генами при пухлинному рості, на тлі дерегулювання обміну арахідонату і ксенобіотиків [11]. Представлений аналіз порушень обміну (на основі використання бази даних генів метаболізму Ara X) показав, що потенційною стратегією гальмування пухлинного росту може з'явитися або модуляція активності компонентів Ara X, або блокування Keap1 — Nrf3 сигналізації у пухлинних клітинах.

Останніми роками новий імпульс розвитку отримав процес ідентифікації біомаркерів порушень клітинного обміну в умовах клініки [13, 18, 26$]$.

Tак, GEMs-моделі, що продемонстрували в ряді випадків високий потенціал щодо індикації біомаркерів, у подальшому отримали підтвердження своєї ефективності методом аналізу метаболому плазми крові. Використовуючи математичне моделювання обміну речовин гепатоцитів вдалося вивчити їх метаболічне перепрограмування у відповідь на розвиток неалкогольної жирової хвороби печінки [13]. Завдяки проведеному аналізу вдалося показати, що на тлі неалкогольного стеатогепатиту (НАСГ), що розвивався у пацієнтів, відбувалося істотне зниження експресії генів ферментів біосинтезу серину та гліцину, завдяки чому виявлено ініціювання підвищення рівня гомоцистеїну в плазмі крові, а також зниження рівня фосфатидилсерину в печінці.

У дослідженні [26] отримано підтвердження зроблених раніше висновків. Виявилося, що пацієнти з НАСГ мали серинову недостатність, а добавки серину з їжею поліпшували стан здоров’я даної категорії пацієнтів. Автори вважають за можливе використання рівнів вмісту серину та гліцину в плазмі крові як неінвазивних біомаркерів розвитку НАСГ при печінковій патології.

Нарешті, проведений у недавньому дослідженні [18] аналіз мереж метаболічних реакцій показав стійкий зв'язок між рівнем манози в плазмі крові та інсулінорезистентністю.

Аналіз інтегрованого масиву даних математичного моделювання метаболізму в адипоцитах і даних транскрипційних мереж, а також мереж білок-білкової взаємодії показав наявність у пацієнтів з надмірною масою тіла ознак дизрегуляції метаболізму манози і підтвердив правильність прогностичних висновків авторів щодо рівня манози в плазмі крові, індексу маси тіла й інсулінорезистентності. Автори вважають, що маноза є одним з важливих метаболітів плазми крові та сильним прогностичним маркером.

\section{Висновки.}

1. Кількісний системний аналіз може дати нове уявлення про молекулярні механізми в клітині, сформувати нові концепції організації, координації і регулювання клітинних процесів. Украй необхідна конвергенція експериментального та in silico аналізу як окремих клітинних процесів, так і технологічних мереж.

2. Системно-біологічний і системно-медичний аналізи вимагають широкого застосування мультидисциплінарних і трансдисциплінарних підходів, як це було продемонстровано на прикладі секвенування цілих геномів.

3. Запропоновано використовувати багатоступеневу систему математичного моделювання в форматі in silico з оцінкою вірогідності кожної з ключових подій, що забезпечують виконання каскаду біохімічних реакцій.

\section{Література.}

1. Биомедицина - 2040. Горизонты науки глазами ученых / Под. ред. В. Н. Княгинина, М. С. Липецкой. - СПб. : фонд «Центр стратегических разработок «Северо-Запад», 2017. - 95 с.

2. A branched-chain amino acid-related metabolic signature that differentiates obese and lean human and contributes to insulin resistance / C. B. Newgard, J. An, J. R. Bain [et al.] // Cell Metab. —2009. — Vol. 9, No. 4. - P. 311-326.

3. A community-driven global reconstruction of human metabolism / I. Thiele, N. Swainston, R. M. Fleming [et al.] // Nat. Biotechnol. - 2013. — Vol. 31, No 5. - P. 419-425.

4. A genome-wide association study of metabolic trials in human urine / K. Suhre, H. Wallaschofski, J. Raffler [et al.] // Nat. Genet. — 2011. — Vol. 43, No. 6. — P. 565-569.

5. A genome-wide association study of the human metabolome in acommunity-based cohort / E. P. Rhee, J. E. Ho, M. H. Chen [et al.] // Cell Metab. — 2013. — Vol. 18, No. 1. - P. 130-143.

6. Cuperlovic-Culf M. Medicine learning method for analysis of metabolic date and metabolic pathway modeling / M. Cuperlovic-Culf // Metabolites. - 2018. — Vol. 8, No. 1. - pii: E4.

7. Deep learning for computational biology / C. Angermueller, T. Parnamqa, L. Parts, O. Stegle // Mol. Syst. Biol. — 2016. — Vol. 12., No. 7 - P. 878. 
8. Defining the human adipose tissue proteome to reveal metabolic alterations in obesity / A. Mardinoglu, C. Kampf, A. Asplund [et al.] // J. Proteome Res. 2014. — Vol. 13, No. 11. - P. 5106-5115.

9. Dimitrov D. V. Medical internet of things and big data in healthcare / D. V. Dimitrov // Healthc. Inform. Res. - 2016. - Vol. 22, No. 3. - P. 156-163.

10. Diversion of aspartate in ASS1-deficient tumors' foster de novo pyrimidine synthesis / S. Rabinovich, L. Adler, K. Yizhak [et al.] // Nature. — 2015. — Vol. 527, No. 7578. - P. 379-383.

11. Gatto F. Systematic analysis reveals than cancer mutations converge on deregulated metabolism of arachidonate and xenobiotics / F. Gatto, A. Schulze, J. Nielsen // Cell Rep. — 2016. — Vol. 16, No. 3. P. 878-895.

12. Genome-scale metabolic modeling elucidates the role of proliferative adaptations in causing the Warburg effect / T. Shlomi, T. Benyamini, E. Gottlieb [et al.] // PLoS Comput. Biol. - 2011. — Vol. 7, No. 3. - P. e1002018.

13. Genome-scale metabolic modeling of hepatocytes reveals serine deficiency in patients with non-alcoholic patty acid disease / A. Mardinoglu, R. Argen, C. Kampt [et al.] // Nat. Commun. - 2014. — Vol. 13. — P. 3083.

14. Global reconstruction of the human metabolic network based on genomic and bibliomic data / N. C. Duarte, S. A. Becker, N. Jamshidi [et al.] // Proc. Natl. Acad. Sci. USA. - 2007. - Vol. 104, No. 6. - P. 1777-1782.

15. Gorski S. Systems biology in the cell nucleus / S. Gorski, T. Misteli // J. Cell Sci. — 2005. — Vol. 118, Pt 18. P. 4083-4092.

16. HMDB 3.0 - The Human Metabolome Database / D. S. Wishart, T. Jewison, A. C. Guo [et al.] // Nucleic Acids Res. - 2013. — Vol. 41. — P. D801-D807.

17. Identification of anticancer drugs for hepatocellular carcinoma through personalized genome-scale metabolic modally / R. Agren, A. Mardinoglu, A. Asplund [et al.] // Mol. Syst. Biol. — 2014. - Vol. 10. — P. 721.

18. Integrated network analysis reveals an association between plasma mannose levels and insulin resistance / S. Lee, C. Zhang, M. Kilicarslan [et al.] // Cell Metab. — 2016. - Vol. 24, No. 1. — P. 172-184.

19. Integration of clinical data with a genome-scale metabolic models of the human adipocytes / A. Mardinoglu, R. Agren, C. Kampf [et al.] // Mol. Syst. Biol. — 2013. - Vol. 9. - P. 649.

20. Mardinoglu A. New paradigms for metabolic modeling in human cell / A. Mardinoglu, J. Nielsen // Curr. Opin. Biotechnol. - 2015. — Vol. 34. — P. 91-97.

21. Modeling cancer metabolism on a genome scale / K. Yizhak, B. Chaneton, E. Gottlieb, E. Ruppin // Mol. Syst. Biol. - 2015. - Vol. 11, No. 6. - P. 817.

22. Multiscale modeling of metabolism and macromolecular synthesis in E. coli and its applications to the evolution of colon usage / I. Thiele, R. M. Fleming, R. Que [et al.] // PLoS ONE. — 2012. — Vol. 7, No. 9. — P. e45635.
23. O’Brien E. J. Using genome-scale models to predict biological capabilities / E. J. O’Brien, J. M. Monk, B. O. Palsson // Cell. — 2015. — Vol. 161, No. 5. — P. 971-987.

24. Palsson B. The challenges of integrating multiomic data sets / B. Palsson, K. Zengler // Nat. Chem. Biol. — 2010. — Vol. 6, No. 11. - P. 787-789.

25. Patil K. R. Uncovering transcriptional regulation of metabolism by metabolic network topology / K. R. Patil, J. Nielsen // Proc. Natl. Acad. Sci. USA. — 2005. Vol. 102, No. 8. - P. 2685-2689.

26. Personal model-assisted identification of NAD+ and glutathione metabolism as intervention target in NAFLD / A. Mardinoglu, E. Bjornson, C. Zhang [et al.] // Mol. Syst. Biol. - 2016. — Vol. 13, No. 3. — P. 91610.

27. Predicting selective drug targets in cancer through metabolic networks / O. Folger, L. Jerby, C. Frezza [et al.] // Mol. Syst. Biol. — 2011. — Vol. 7. — P. 501.

28. Proteome- and transcriptome-driven reconstruction of the human myocyte metabolic network and its use for identification of markers for diabetes / L. Väremo, C. Sheele, C. Broholm [et al.] // Cell. Rep. — 2015. — Vol. 11, No. 6. - P. 921-933.

29. Proteomics. Tissue-based map of the human proteome / M. Uhlén, L. Fagerberg, B. M. Hallström [et al.] // Science. — 2015. — Vol. 347, No. 6220. — P. 1260419.

30. The Edinburgh human metabolic network reconstruction and its functional analysis / H. Ma, A. Sorokin, A. Mazein [et al.] // Mol. Syst. Biol. — 2007. — Vol. 3. - P. 135.

31. The human serum metabolome/ N. Psychodios, D. A. Hau, J. Peng [et al.] // PLoS ONE. - 2011. Vol. 6, No. 6. - P. e16957.

32. The relationship between branched-chain aminoacid related metabolism signature and insulin resistance: a systematic review / X. Zhao, Q. Han, Y. Liu [et al.] // J. Diabetes Res. — 2016. — Vol. 2016. — P. 2794591.

\section{References.}

1. Knyaginin, V. N., \& Lipetskaya, M. S. (Eds.) (2017). Biomeditsina - 2040. Gorizonty nauki glazami uchenykh [Biomedicine - 2040. Horizons of science through the eyes of scientists]. St. Petersburg: fond «Tsentr strategicheskikh razrabotok «Severo-Zapad» (fund «Center for Strategic Research «North-West»). [In Russian].

2. Newgard, C. B., An, J., Bain, J. R., Stevens, R. D., Lien, L. F., Haqq, A. M., ... Svetkey, L. P. (2009). A branchedchain amino acid-related metabolic signature that differentiates obese and lean human and contributes to insulin resistance. Cell Metab., 9(4), 311-326. doi: 10.1016/j.cmet.2009.02.002.

3. Thiele, I., Swainston, N., Fleming, R. M., Hoppe, A, Sahoo, S, Aurich, M. K., ... Palsson, B. Ø. (2013). A community-driven global reconstruction of human 
metabolism. Nat. Biotechnol., 31(5), 419-425. doi: 10.1038/nbt.2488.

4. Suhre, K., Wallaschofski, H., Raffler J., Friedrich, N, Haring, R, Michael, K., ... Nauck, M. (2011). A genomewide association study of metabolic traits in human urine. Nat. Genet., 43(6), 565-569. doi: 10.1038/ng.837.

5. Rhee, E. P., Ho, J. E., Chen, M. H., Shen, D, Cheng, S, Larson, M. G., ... Gerszten, R. E. (2013). A genomewide association study of the human metabolome in acommunity-based cohort. Cell Metab., 18(1), 130-143. doi: 10.1016/j.cmet.2013.06.013.

6. Cuperlovic-Culf, M. (2018). Medicine learning method for analysis of metabolic date and metabolic pathway modeling. Metabolites, 8(1), E4. doi: 10.3390/ metabo8010004.

7. Angermueller, C., Parnamqa, T., Parts, L., \& Stegle, O. (2016). Deep learning for computational biology. Mol. Syst. Biol., 12(7), 878. doi: 10.15252/msb.20156651.

8. Mardinoglu, A., Kampf, C., Asplund, A., Fagerberg, L, Hallström, B. M., Edlund, K, ... Nielsen, J. (2014). Defining the human adipose tissue proteome to reveal metabolic alterations in obesity. J. Proteome Res., 13(11), 5106-5115. doi: 10.1021/pr500586e.

9. Dimitrov, D. V. (2016). Medical internet of things and big data in healthcare. Healthc. Inform. Res., 22(3), 156-163. doi: 10.4258/hir.2016.22.3.156.

10. Rabinovich, S., Adler, L., Yizhak, K., Sarver, A, Silberman, A, Agron, S., ... Erez, A. (2015). Diversion of aspartate in ASS1-deficient tumors' foster de novo pyrimidine synthesis. Nature, 527(7578), 379-383. doi: 10.1038/nature15529.

11. Gatto, F., Schulze, A., \& Nielsen, J. (2016). Systematic analysis reveals than cancer mutations converge on deregulated metabolism of arachidonate and xenobiotics. Cell Rep., 16(3), 878-895. doi: 10.1016/j. celrep.2016.06.038.

12. Shlomi, T., Benyamini, T., Gottlieb, E., Sharan, R, \& Ruppin, E. (2011). Genome-scale metabolic modeling elucidates the role of proliferative adaptations in causing the Warburg effect. PLoS Comput. Biol., 7(3), e1002018. doi: 10.1371/journal.pcbi.1002018.

13. Mardinoglu, A., Argen, R., Kampt, C., Asplund, A., Uhlen, M., \& Nielsen, J. (2014). Genome-scale metabolic modeling of hepatocytes reveals serine deficiency in patients with non-alcoholic patty acid disease. Nat. Commun., 5, 3083. doi: 10.1038/ ncomms4083.

14. Duarte, N. C., Becker, S. A., Jamshidi, N., Thiele, I., Mo, M. L., Vo, T. D., ... Palsson, B. Ø. (2007). Global reconstruction of the human metabolic network based on genomic and bibliomic data. Proc. Natl. Acad. Sci. USA, 104(6), 1777-1782. doi: 10.1073/pnas.0610772104.

15. Gorski, S., \& Misteli, T. (2005). Systems biology in the cell nucleus. J. Cell Sci., 118(Pt 18), 4083-4092. doi: 10.1242/jcs.02596.
16. Wishart, S., Jewison, T., Guo, A. C., Wilson, M., Knox, C., Liu, Y., ... Scalbert, A. (2013). HMDB 3.0 - The Human Metabolome Database in 2013. Nucleic Acids Res., 41, D801-807. doi: 10.1093/nar/gks1065.

17. Agren, R., Mardinoglu, A., Asplund, A., Kampf, C, Uhlen, M, \& Nielsen, J. (2014). Identification of anticancer drugs for hepatocellular carcinoma through personalized genome-scale metabolic modally. Mol. Syst. Biol., 10, 721. doi: 10.1002/msb.145122.

18. Lee, S., Zhang, C., Kilicarslan, M., Piening, B. D., Bjornson, E., Hallström, B. M., ... Mardinoglu, A. (2016). Integrated network analysis reveals an association between plasma mannose levels and insulin resistance. Cell Metab., 24(1), 172-184. doi: 10.1016/j. cmet.2016.05.026.

19. Mardinoglu, A., Agren, R., Kampf, C., Asplund, A., Nookaew, I., Jacobson, P., ... Nielsen, J. (2013). Integration of clinical data with a genome-scale metabolic models of the human adipocytes. Mol. Syst. Biol., 9, 649. doi: 10.1038/msb.2013.5.

20. Mardinoglu, A., \& Nielsen, J. (2015). New paradigms for metabolic modeling in human cell. Curr. Opin. Biotechnol., 34, 91-97. doi: 10.1016/j. copbio.2014.12.013.

21. Yizhak, K., Chaneton, B., Gottlieb, E., \& Ruppin, E. (2015). Modeling cancer metabolism on a genome scale. Mol. Syst. Biol., 11(6), 817. doi: 10.15252/ msb.20145307.

22. Thiele, I., Fleming, R. M., Que, R., Bordbar, A., Diep, D., \& Palsson, B. O. (2012). Multiscale modeling of metabolism and macromolecular synthesis in E. coli and its applications to the evolution of colon usage. PLoS ONE, 7(9), e45635. doi: 10.1371/journal.pone.0045635.

23. O’Brien, E. J., Monk, J. M., \& Palsson, B. O. (2015). Using genome-scale models to predict biological capabilities. Cell, 161(5), 971-987. doi: 10.1016/j. cell.2015.05.019.

24. Palsson, B. \& Zengler, K. (2010). The challenges of integrating multiomic data sets. Nat. Chem. Biol., 6(11), 787-789.

25. Patil, K. R., \& Nielsen, J. (2005). Uncovering transcriptional regulation of metabolism by metabolic network topology. Proc. Natl. Acad. Sci. USA, 102(8), 2685-2689. doi: 10.1073/pnas.0406811102.

26. Mardinoglu, A., Bjornson, E., Zhang, C., Klevstig, M., Söderlund, S., Ståhlman, M., ... Boren, J. (2016). Personal model-assisted identification of NAD+ and glutathione metabolism as intervention target in NAFLD. Mol. Syst. Biol., 13(3), 91610. doi: 15252/ wsb.20167422.

27. Folger, O., Jerby, L., Frezza, C., Gottlieb, E., Ruppin, E., \& Shlomi, T. (2011). Predicting selective drug targets in cancer through metabolic networks. Mol. Syst. Biol., 7, 501. doi: 10.1038/msb.2011.35.

28. Väremo, L., Sheele, C., Broholm, C., Mardinoglu, A., Kampf, C., Asplund, A., ... Nielsen, J. (2015). Proteome- 
and transcriptome-driven reconstruction of the human myocyte metabolic network and its use for identification of markers for diabetes, Cell. Rep., 11(6), 921-933. doi: 10.1016/j.celrep.2015.04.010.

29. Uhlén, M., Fagerberg, L., Hallström, B. M., Lindskog, C., Oksvold, P., Mardinoglu, A., ... Pontén, F. (2015). Proteomics. Tissue-based map of the human proteome. Science, 347(6220), 1260419. doi: 10.1126/ science.1260419.

30. Ma, H., Sorokin, A., Mazein, A., Selkov, A., Selkov, E., Demin, O., \& Goryanin, I. (2007). The Edinburgh human metabolic network reconstruction and its functional analysis. Mol. Syst. Biol., 3, 135. doi: 10.1038/ msb4100177.

31. Psychodios, N., Hau, D. D., Peng, J., Guo, A. C., Mandal, R., Bouatra, S., ... Wishart, D. S. (2011). The human serum metabolome. PLoS ONE, 6(2), e16957. doi: 10.1371/journal.pone.0016957.

32. Zhao, X., Han, Q., Liu, Y., Sun, C., Gang, X., \& Wang, G. (2016). The relationship between branched-chain aminoacid related metabolism signature and insulin resistance: a systematic review. J. Diabetes Res., 2016, 794591. doi: 10.1155/2016/2794591. 